NBER WORKING PAPER SERIES

\title{
INNOVATION AND PRODUCTIVITY ACROSS FOUR EUROPEAN COUNTRIES
}

\author{
Rachel Griffith \\ Elena Huergo \\ Jacques Mairesse \\ Bettina Peters \\ Working Paper 12722 \\ http://www.nber.org/papers/w12722 \\ NATIONAL BUREAU OF ECONOMIC RESEARCH \\ 1050 Massachusetts Avenue \\ Cambridge, MA 02138 \\ December 2006
}

We would like to thank Laura Abramovsky, Manuel Arellano, Rupert Harrison, Jordi Jaumandreu, Elizabeth Kremp, Pierre Mohnen, Helen Simpson. The analysis contained in this paper was funded by the European Commission, the ESRC and ESF under grant RES-000-23-0901 and the Advanced Institute of Management Research (AIM). All errors and omissions remain the responsibility of the authors. The views expressed herein are those of the author(s) and do not necessarily reflect the views of the National Bureau of Economic Research.

(C) 2006 by Rachel Griffith, Elena Huergo, Jacques Mairesse, and Bettina Peters. All rights reserved. Short sections of text, not to exceed two paragraphs, may be quoted without explicit permission provided that full credit, including $(\mathrm{C}$ notice, is given to the source. 
Innovation and Productivity across Four European Countries

Rachel Griffith, Elena Huergo, Jacques Mairesse, and Bettina Peters

NBER Working Paper No. 12722

December 2006

JEL No. L1,L60,O31,O33,O47

\section{ABSTRACT}

This paper compares the role innovation plays in productivity across the four European countries France, Germany, Spain and the UK using firm-level data from the internationally harmonized Community Innovation Surveys (CIS3). Despite a considerable number of national firm-level studies analysing this relationship, cross-country comparisons using micro data are still rare. We apply a structural model that describes the link between R\&D expenditure, innovation output and productivity (CDM model). Our econometric results suggest that overall the systems driving innovation and productivity are remarkably similar across these four countries, although we also find interesting differences, particularly in the variation in productivity that is associated with more or less innovative activities.

Rachel Griffith

IFS

7 Ridgmont Street

London WC1E 7AE

UK

rgriffith@ifs.org.uk

Elena Huergo

Universidad Complutense

Facultad CC. Económicas y Empresariales

Campus de Somosaguas

28223 Madrid - Spain

ehuergo@ccee.ucm.es
Jacques Mairesse

INSEE, CREST

15, Boulevard Gabriel PERI

92245 MALAKOFF CEDEX

FRANCE

and NBER

mairesse@ensae.fr

Bettina Peters

ZEW

Postfach 103443 D-68043 Mannheim

Germany

b.peters@zew.de 


\section{Introduction}

The poor productivity performance of European countries relative to the US has been an important focus for government policy. Table 1 shows aggregate productivity levels and growth rates in $2000 .{ }^{1}$ But, it is not only that Europe is lagging behind the US, but that there are also larger differences across European countries in labour productivity development, for instance between Spain at the lower and the UK at the upper bound. Emphasis has been placed on the need for Europe to move into the "knowledge-based economy". Post-war growth in Europe, it is argued, was largely based on imitation, driven by capital accumulation, while what is needed now is for European countries to shift towards growth based on innovation. ${ }^{2}$ In fact, R\&D intensity in the four major EU countries (France, Germany, Spain and the UK) lies behind US as can be seen in Table 1.

\section{[Table 1 here]}

What role does innovation play in productivity growth across European countries? There are two major challenges facing researchers trying to answer this question - how do we measure innovation and can we get data that are comparable across countries? Commonly used measures of innovation are $R \& D$ expenditures or patent counts. While both have strengths as measures of innovation they also have weaknesses. R\&D is a measure of inputs, and takes no account of the productivity and effectiveness of effort. Patents are a crude measure of outputs, capturing only some sorts of invention, and being of very differing values.

In this paper, we use comparative data across European countries at the firm level from the harmonized Community Innovation Surveys (CIS data), which provides indicators of innovation input and outcomes. Our interest focuses in comparing firm-level innovation and productivity behaviour across countries, which has been hampered in the past due to a lack of internationally comparable data, in particular as concerns innovation. Precisely we estimate a structural model for

\footnotetext{
${ }^{1}$ We report figures for the end of the nineties to 2000 in Table 1 because it is the time span of the data we used in the econometric part. More recent data still confirms this pattern across the countries.

${ }^{2}$ See, for example, EU (2003), Aghion and Howitt (1998).
} 
manufacturing firms in France, Germany, Spain and the UK, that directly links R\&D to innovation outcomes and then links innovation to productivity. This allows us to disentangle the contribution of R\&D intensity per se from the effectiveness of innovative effort in leading to productivity gains. ${ }^{3}$

In summary, our results suggest that overall the systems driving innovation and productivity are remarkably similar across France, Germany, Spain and the UK, although we also find interesting differences, particularly in the variation in productivity that is associated with more or less innovative activities.

The paper is organized as follows. Section II explains the framework and describes the data. Section III presents the results and some robustness checks. Section IV concludes. Appendix A provides a formal description of the econometric model estimated, and Appendix B comments the data in more detail.

\section{Model and Data}

\section{II.i Model}

In this paper we apply a structural model which has the following basic form: firms decide how much effort to put into innovation; knowledge is produced as a result of this investment; output is produced using knowledge (along with other inputs). This model is formalised in four equations: (i) the firm's decision to engage in sufficient effort to result in observable research and development (R\&D) investment, (ii) the intensity with which the firm undertakes $R \& D$, or $R \& D$ investment function, (iii) the innovation or knowledge production function, where we allow knowledge to take two different forms - process and product innovations, and (iv) the output production function, where

\footnotetext{
3 “The productivity of innovative effort" is what Mairesse and Mohnen in comparable work propose to call for short “innovativeness” or “innovativity”. See Mairesse and Mohnen (2002, 2005) and Mohnen et al. (2006).
} 
knowledge is an input. The model is based on Crépon, Duguet and Mairesse (1998), henceforth called CDM model. ${ }^{4}$ Technical details on the model and its estimation are given in Appendix A.

In contrast to most previous studies we estimate the CDM model not only for innovative but for all firms. That is, we estimate step (i) and (ii) based on reported R\&D figures and use predicted values for all firms to proxy innovation effort in the knowledge production function. This model reflects the fact that all firms exert some innovative effort, but not all firms report this effort. ${ }^{5}$ For example, production workers may well spend a small part of their day considering how the process they are working on could be achieved more efficiently. However, below a certain threshold, a firm will not report this effort as $R \& D$. The output of this innovation effort produces knowledge. As indicated above, we allow knowledge output to take several forms, including process and product innovations, and we assume that effort is a public good within the firm, so it can be used to produce several outputs without depletion. We estimate the relationship between R\&D investment and process and product innovation outputs using data on firms that report both, and impute knowledge output for all firms based on these estimates. The idea is that we believe that a firm that reports zero R\&D does not actually have zero knowledge output. This approach assumes that the process describing R\&D investment and innovation outputs for non $R \& D$ reporting firms is the same as for reporting firms.

\footnotetext{
${ }^{4}$ Other studies which have used different versions of the CDM model include Lööf and Heshmati (2002, 2006) for Swedish manufacturing firms, Klomp and Van Leeuwen (2001) and Van Leeuwen and Klomp (2006) using Dutch manufacturing data, Criscuolo and Haskell (2003) using UK CIS1 and CIS2 data, Janz et al. (2004) using German and Swedish CIS3 data, Parisi et al. (2005) using data for Italian manufacturing firms, Mairesse and Mohnen (2002, 2005) and Mohnen et al. (2006) using French CIS1 and CIS3 data, Benavente (2006) for Chilean firms, Jefferson (2006) for a panel of Chinese firms, Peters (2006) for a panel of German firms. See also Hall and Mairesse (2006). For a presentation of the more traditional approach of estimating $R \& D$ productivity and rate of returns directly in terms of an extended production function, see, inter alia, Griliches (1979, 1994, 1996) and Griliches and Mairesse (1998).

${ }^{5}$ In addition to R\&D expenditures stricto sensu (as defined by the Frascati manual, OECD 1963), the Community Innovation Surveys also include questions on several other specific innovation expenditures, i.e. expenditures related to the acquisition of other external knowledge, to the acquisition of machinery and equipment and training activities in the context of innovations, to market introduction of innovations, and to design and other preparation activities for the production and delivery of new products (Oslo manual, Eurostat and OECD, 1997). Many firms in the French CIS3 apparently did not understand them well. We have preferred here to stay with the more usual R\&D variable, and not use
} 
Finally, in the model firms produce output using a constant returns to scale Cobb-Douglas technology with labour, capital and knowledge inputs.

We choose this structural model because it captures the main features of firm behaviour, but is at the same time parsimonious and empirically tractable with the data we have available.

\section{II.ii Data and Empirical Implementation}

In this study we take advantage of the data from the third wave of the Community Innovation Surveys (CIS3). The CIS is a harmonised survey that is carried out by national statistical agencies in all 25 EU Member States under the co-ordination of Eurostat. CIS3 was conducted in 2001 and provides information for the period $1998-2000 .{ }^{6}$ To fully exploit the comparable nature of the information we have had to assemble researchers from France, Germany, Spain and the U.K who had access to the underlying original firm level data collected under CIS. ${ }^{7}$ Great care has been taken to make these micro data fully comparable across the four countries, and this is one strength of our investigation. For a more detailed description of the data sets and their comparability across countries see Abramovsky et al (2004).

As mentioned above, we believe that all firms exert some innovative effort, so we use the whole sample of firms, and not only innovating firms. To explain which firms report R\&D we have to take the specific characteristics of the data set into account. One distinctive feature of the CIS questionnaire in France, Germany and Spain is that it asked all firms for a few general information, such as the number of employees and the industry to which the firm belongs, and whether they have (completed, ongoing or abandoned) innovation activities or not. Only those firms with innovation

the “Total innovation expenditures” variable including these other innovation expenditures. Our estimates using this more broadly defined variable, rather than R\&D, are practically unchanged for Germany and Spain.

${ }^{6}$ The survey was also carried out in Iceland and Norway as well as Turkey and Romania. Furthermore other non European countries have carried out surveys equivalent to CIS3.

${ }^{7}$ Eurostat publishes results on a highly aggregated sector level (manufacturing, wholesale trade, producer services) for each country (Eurostat, 2004) and Eurostat's online data base, New Cronos, also only provides information at the sector level. Since recently, Eurostat also proposes access to anonymised micro-aggregated CIS3 data. However, these data are currently available for only 12 out of the 25 EU countries, with Germany, France and the UK not being provided. 
activities are requested to answer to a lot of additional questions, like those on co-operations, information sources etc. R\&D performers are by definition firms with innovation activities. Hence to explain of whether firms have R\&D or not, we can only use limited information available for all firms. We use an indicator of whether the international market is the firm's most important market to capture the exposition to international competition, indicators of whether the firm receives public funding, and measures of appropriability conditions that the firm faces - the extent of legal and formal protection of intellectual property in the country. Effective appropriability conditions are important in that they allow innovators to receive the returns on their innovation activities. As a result, they also increase the incentives for and amount of innovation activities (Spence 1984). We also use size and industry dummy variables, as well as a dummy variable for Eastern Germany in the German sample. Detailed variable definitions are given in Appendix B.

We use a larger set of variables to explain $R \& D$ intensity measured as $R \& D$ expenditures per employee (in logs). Here we also consider demand conditions - whether environmental, health and safety or other regulatory standards were an important reason for innovating - along with an indicator of whether the enterprise had some co-operative arrangements on innovation activities during 19982000, a set of categorical variables reflecting different sources of information for innovation and indicators for public support for that firm at the local, national or EU level.

As already stated, we distinguish two different kinds of innovation outcome: product and process innovations. Both are measured by a dummy variable indicating whether the firm has introduced at least one product and process innovation, respectively. In addition to $R \& D$ intensity we explain the innovation outcome by the same group of demand pull indicators and appropriability conditions. Furthermore, we expect firms to be more successful in product innovation activities if they used customers or competitors as information source and in process innovation activities if they used information stemming from their suppliers or competitors. We also include investment per employee in the production of process innovations, because we want to allow for complementarities between process innovation and investment in capital that embodies new process technologies. We do not 
include it in product innovation because we do not see evidence of such complementarities in that case.

Productivity is measured as labour productivity (sales per employee, in logs) and depends on the knowledge measured in terms of product and process innovation outcomes. Since we do not observe physical capital in the data for all countries we proxy for it in the productivity equation by investments in physical capital.

We allow all coefficients to vary across countries (i.e., we estimate our model separately for the four countries). In all equations we control for unobserved industry characteristics. We further control for firm size in all equations but the R\&D intensity equation, R\&D intensity being already implicitly scaled for size. When included in this equation, the size indicators are not significant, and our estimates in the other equations of the model are not affected.

Descriptive statistics of the main variables in the model are reported for the four countries in Table 2. We restrict our analysis to firms with at least 20 employees. $^{8}$ Some differences and similarities are worth noting.

\section{[Table 2 here]}

The proportions of firms reporting that they are engaged in $R \& D$ and have process and product innovations are greater in France and Germany than in Spain or the UK. French and German firms that do R\&D also do so more intensively than their Spanish and U.K counterparts, i.e. R\&D intensity of R\&D-performers is much higher. This confirms the general pattern found at the aggregate level in Table 1. Note that in results not shown the performance in terms of shares of sales for new or substantially improved products is about the same for the German, Spanish and UK product innovating firms, but higher than for the French firms, which are less successful in commercializing their innovative products. French firms draw on formal measures to protect returns from innovation

\footnotetext{
${ }^{8}$ In Germany, the UK and Spain, the CIS3 covers all enterprises with 10 or more employees. In France, however, the target population for manufacturing includes firms with 20 or more employees. We restrict ourselves to firms with over 20 employees so we can compare the four countries. The number of firms by industry in each country is given in the data Appendix Table B.1.
} 
almost as often as German or UK firms, but less often on strategic measures. On the other hand, Spanish firms use both formal and strategic protection measures much less frequently (though they have a high share of innovative sales). Average labour productivity in manufacturing is highest in France, and is similar in the UK and Germany, but lower in Spain, which is also what we see at the aggregate level in Table 1 in terms of GDP per employee. Investment per employee is higher in Spain than in the other three countries. This may be in part because the average size of Spanish firms is smaller - average firm number of employees is only 74 for Spain, as compared to 142 in France, 155 in Germany and 116 in the UK.

Other notable differences are the following: public support for R\&D is lower in the U.K; government is also less of a source of information in the UK; universities are a greater source of information in Germany; and Spanish and UK firms face less international competition in the sense that international markets are less often the firm’s most important market.

\section{Results}

We now turn to a discussion of the estimates of the parameters of the structural model described above and formally set out in Appendix A. Before interpreting the results we point to an important caveat of the study: we only have cross-section data, and most of the factors we consider are simultaneously determined. Therefore, we need to take great care in interpreting our results - all we are able to recover are correlations, these are not necessarily causal relationships.

\section{III.i R\&D and R\&D intensity}

We start by considering estimates of the determinants of whether firms undertake $R \& D$, and if so how much R\&D. The first four columns (left hand panel) in Table 3 show estimates of the determinants of whether a firm engages in R\&D continuously over the period 1998-2000, with one column for each country. As discussed above (in section II.i), we consider all firms as engaging in innovative activity, but only some engaging in a sufficient amount for it to be reported as "continuous R\&D”. In the first panel we estimate a discrete (probit) model. The second four columns (right hand 
panel) in Table 3 show the corresponding estimates of the determinants of how much firms invest in $\mathrm{R} \& \mathrm{D}$, conditional on doing $\mathrm{R} \& \mathrm{D}$.

The numbers reported in these tables are marginal effects. All of the explanatory variables are dummy variables - they take the value 1 when the factor is important to the firm or is used by the firm (see precise definitions in the Data Appendix B) and the value zero if it is unimportant or not used. Therefore, the "marginal" effect is that of changing the dummy variable from 0 to 1.

\section{[Table 3 here]}

Consider the coefficients on the Funding variables. These tell us that French firms that receive funding from national sources are $25 \%$ more likely to report engaging in continuous R\&D than firms that receive no funding from national sources - conditional on the mean values of all of the other variables. In Germany firms that receive national funding are 40.8\% more likely, in Spain 27.3\% more likely, and in the UK 19\% more likely. The marginal effect of national funding will differ across countries due to differences in the funding system as well as potential differences in firm behaviour.

Overall, the marginal effects reported in Table 3 are surprisingly similar across countries. They suggest as a whole that broadly comparable processes, in broadly comparable economic environment, drive firms' decisions to engage in R\&D across the major European countries. Specifically, what we see is that:

- firms that operate mainly in international markets are more likely to engage in $R \& D$; and they engage in R\&D more intensively (only significantly so in France and Spain);

- firms in industries where greater use is made of formal or strategic methods to protect innovations are more likely to invest in $R \& D$ but given the decision to invest in $R \& D$, protection measures have almost no impact on the amount of R\&D. In Germany strategic methods are much more important than formal methods, whereas in other countries they are similar. Note that the weakly negative impact coefficient of strategic measures in Spain stands out as an exception. 
- receiving government funding increases the probability that a firm engages in $R \& D$ continuously, national funding has the largest impact; receiving government funding, however, has very little impact on the intensity of $R \& D$, although national funding does have some positive impact in Germany and Spain, but a negative impact in France and no impact in the UK;

- larger firms are more likely to engage in $\mathrm{R} \& \mathrm{D}{ }^{9}{ }^{9}$

- firms in East Germany are more likely to undertake R\&D than those in West Germany. This result is also observed at the aggregate level, for instance in 2000 the share of continuous R\&D performers in East Germany was $28 \%$ as against 24\% in West Germany (see Aschhoff et al., 2006). This is explained by the existence of special support programmes for firms located in Eastern Germany to help them catch up on the productivity of West German firms. ${ }^{10}$

\section{III.ii Knowledge production functions}

We next consider the estimates of the knowledge production functions in Table 4. The first four columns (left-hand panel) show them for process innovation, the four last columns (right-hand panel) for product innovation. The numbers reported are again marginal effects evaluated at the sample means. All of the explanatory variables except the first two are dummy variables - they take the value 1 when the factor is important to the firm and the value zero if it is unimportant, and as before the “marginal” effects are those of changing their value from 0 to 1.

\section{[Table 4 here]}

As expected, the marginal effects for R\&D intensity are both statistically and economically very significant. They show most clearly that greater R\&D effort per employee leads to a higher probability of having at least one process innovation and of having at least one product innovation. The impacts are again remarkably similar across the four countries, although lower for process

\footnotetext{
${ }^{9}$ As already indicated, we exclude the firm size indicators from the R\&D intensity equation, but if we include them they are insignificant.
} 
innovation in the UK and higher for product innovation in France. Furthermore, the marginal effects for physical investment on process innovation are also quite significant for the four countries, with the impacts being similar although higher in the UK.

The ability to protect an innovation through formal or strategic methods is less important for process innovation than it is for product innovation; although in contrast to the other three countries neither is important in the UK. As expected, suppliers are an important source of information for process innovation, while customers have a considerable influence in stimulating product innovation. Competitors are not such an important source of information (in magnitude as well as in significance) compared to suppliers and customers. Environmental regulations are an important driver of process and product innovation in France, and process innovation in Germany. Standards have a negative impact on process innovation in France.

There is a huge literature dealing with the relationship between firm size and innovation activities. ${ }^{11}$ Our estimates suggest that in all four countries larger firms are more likely to be process innovators (which makes sense whenever process innovation entails a per unit cost reduction). Larger firms also appear more likely to be product innovators, especially in Spain, but not in the UK.

\section{III.iii Output production functions}

Finally, we consider our estimates of the productivity equation shown in Table 5. The coefficients reported in this table are elasticities or semi-elasticities, since the dependent variable is the log of sales per employee.

\section{[Table 5 here]}

In contrast to the results for the $R \& D$ equations and the knowledge production equations, the results for labour productivity are quite mixed across the four countries. We thus find that the

\footnotetext{
${ }^{10}$ Detailed information about the funding policy and its effectiveness in Eastern Germany is given in Czarnitzki and Licht (2006).

11 This literature has been initiated by J. Schumpeter who asserted that large firms in highly concentrated markets have an advantage in innovation, or so called first Schumpeter hypothesis. For a survey of empirical studies testing such hypothesis, see, for example, Cohen and Klepper (1996).
} 
elasticities of output with respect to investment are close in France and Germany (0.13 in France and 0.11 in Germany) and significantly higher than in Spain and the UK (0.06 in both). This is on the low side for Spain and the UK, but in line with some previous estimates in the literature using similar data. $^{12}$

The process and product innovation impact coefficients appear even more different in the four countries. The estimated coefficient of process innovation in France is the only statistically significant one, suggesting that process innovation is on average associated with a $6 \%$ increase in productivity. In the other countries there is surprisingly no such association, which could correspond to the fact that we are measuring revenue productivity (deflated by industry deflators, not by individual firm deflators). ${ }^{13}$ The estimated coefficients of product innovation are significant in France, Spain and the UK, but not for Germany, accounting for a $18 \%$ increase in productivity in Spain, and a more modest one of about $6 \%$ in France and the UK. ${ }^{14}$

\section{Summary and Conclusions}

This paper investigates the drivers of innovation and how they feed through into productivity at the firm-level for the four major European countries - France, Germany, Spain, and the UK - using data from the third wave of the internationally harmonized Community Innovation Surveys. We estimate a structural model that describes the link between R\&D expenditures, innovation output and productivity. Importantly, this model allows for the fact that some firms may undertake innovate efforts but do not report them as R\&D.

What do our results imply for policy? In response to recent concerns about lagging productivity and poor innovative performance in Europe countries, the European Union has set itself the ambitious target of increasing R\&D expenditures to 3\% of GDP by 2010 (this is part of the "Lisbon Agenda").

\footnotetext{
${ }^{12}$ See, for example, Huergo and Moreno (2006) for Spanish manufacturing.

${ }^{13}$ On this issue, see for example Mairesse and Jaumandreu (2005).
} 
Does the EU's poor performance lie primarily in low investment in $R \& D$, or is the main problem that EU firms do not exploit their innovations well? Are the returns to innovative efforts and to innovations similar across countries, or do they vary, and so does policy need to have a different focus in the different countries?

As we stressed in presenting our results, a major drawback of the CIS is that it is a series of crosssections, so we do not observe many of the same firms repeatedly over time. This means that we need to take great care in interpreting our results - all we are able to recover is correlations, these are not necessarily causal relationships.

Bearing that caveat in mind, our results show some interesting regularities and some heterogeneity between the countries. In terms of firms' decision over whether or not to engage in formal $R \& D$ the determinants are remarkably similar across countries. This suggests that broadly comparable processes drive firms' decisions to engage in R\&D across the major European countries. Government funding plays an important role in all countries, with national funding having the largest impact. Firms that operate mainly in international markets and larger firms are more likely to engage in formal $R \& D$, as are firms in industries where greater use is made of formal or strategic methods to protect innovation.

Unsurprisingly, firms’ greater R\&D effort per employee made them more likely to be process or product innovators. Furthermore, firms with higher investment per employee are also more likely to be process innovators. The ability to protect an innovation through formal or strategic methods is less important for process innovation than it is for product innovation. Suppliers are an important source of information for process innovation, while customers are significant in stimulating product innovation. Competitors are not such an important source of information (in magnitude as well as in significance) compared to suppliers and customers.

\footnotetext{
${ }^{14}$ It must be noted that our poor estimates of the productivity impacts of process and product innovations in Germany are not in line with more positive results found by Janz et al. (2004) for knowledge intensive firms and by Peters (2006) for the more recent period 2000-2002.
} 
In contrast to the large coincidence found for the R\&D equations and the knowledge production equations, the results for labour productivity are quite mixed across the four European countries. Process innovation is only associated with higher productivity in France, in the other countries there is no such connection. Product innovation is associated with higher productivity in France, Spain and the UK, but not in Germany. 


\section{Appendix A: Econometric Model}

Formally we can write our model as follows. Let $i=1, \ldots, N$ index firms. The first equation accounts for firms' innovative effort $r_{i}^{*}$ :

$$
r_{i}^{*}=z_{i}^{\prime} \beta+e_{i}
$$

where we consider $r_{i}^{*}$ as an unobserved latent variable, and where $z_{i}$ is a vector of determinants of innovation effort, $\beta$ is a vector of parameters of interest, and $e_{i}$ an error term. We can measure (or proxy) firms' innovative effort $r_{i}^{*}$ by their R\&D expenditures, denoted by $r_{i}$ only if firms do (and/or report) such expenditures, and thus could only directly estimate equation (1) at the risk of selection bias. Instead we assume the following selection equation describing whether a firm is doing (and/or reporting) R\&D or not:

$$
r d_{i}=\left\{\begin{array}{lll}
1 & \text { if } & r d_{i}^{*}=w_{i}^{\prime} \alpha+\varepsilon_{i}>c \\
0 & \text { if } & r d_{i}^{*}=w_{i}^{\prime} \alpha+\varepsilon_{i} \leq c
\end{array},\right.
$$

where $r d_{i}$ is the observed binary endogenous variable equal to zero for non-R\&D and one for $R \& D$ doing (and/or reporting) firms, $r d_{i}^{*}$ is a corresponding latent variable such that firms decide to do (and/or report) R\&D if it is above a certain threshold level $c$, and where $w_{i}$ is a vector of variables explaining the R\&D decision, $\alpha$ a vector of parameters of interest, and $\varepsilon_{i}$ an error term.

Conditional on firm $i$ doing (and/or reporting) R\&D activities, we can observe the amount of resources invested in $\mathrm{R} \& \mathrm{D}$, and write:

$$
r_{i}=\left\{\begin{array}{lll}
r_{i}^{*}=z_{i}^{\prime} \beta+e_{i} & \text { if } & r d_{i}=1 \\
0 & \text { if } & r d_{i}=0
\end{array} .\right.
$$


Assuming that the error terms $e_{i}$ and $\varepsilon_{i}$ are bivariate normal with zero mean, variances $\sigma_{\varepsilon}^{2}=1$ and $\sigma_{e}^{2}$ and correlation coefficient $\rho_{e \varepsilon}$, we estimate the system of equations (2) and (3) as a generalized Tobit model by maximum likelihood (using STATA and Heckman procedure to choose initial values for the parameters).

The next equations in our model are the knowledge or innovation production functions:

$$
g_{i}=r_{i}^{*} \gamma+x_{i}^{\prime} \delta+u_{i}
$$

where $g_{i}$ is knowledge proxied by both the product and process innovation indicators, and where the latent innovation effort, $r_{i}^{*}$, enters as explanatory variable, $x_{i}$ is a vector of other determinants of knowledge production, $(\gamma, \delta)$ a vector of parameters of interest and $u_{i}$ an error term.

We estimate the knowledge production equation (4) as two separate probit equations for the process and product innovation indicators, by maximum likelihood in STATA. For the firms' innovative effort $r_{i}^{*}$ we take the predicted value from the estimated generalized Tobit equations (2) and (3). That is, we estimate (4) for the sample of all firms, not only for the sub-sample of those reporting R\&D expenditures. By using its predicted value, we also instrument the innovative effort $r_{i}^{*}$ and take care that it is possibly endogenous to the knowledge production function. In other words, it seems likely that characteristics of firms unobservable to us (and thus omitted) can make them both increase their innovative effort and also their "innovativity" (i.e. their productivity in producing innovations). This would mean that the $\gamma$ parameters in (4) would be biased upward (because $r_{i}^{*}$ and $u_{i}$ would be positively correlated). The selection and innovative effort equations correct for this (as long as $w_{i}$ and $z_{i}$ are independent of $u_{i}$ ). 
Finally, firms produce output using constant returns to scale Cobb-Douglas technology with labour, capital and knowledge inputs so that,

$$
y_{i}=\pi_{1} k_{i}+\pi_{2} g_{i}+v_{i}
$$

where output $y_{i}$ is labour productivity (log of output per worker), $k_{i}$ is the log of physical capital per worker (proxied by physical investment per worker), and $g_{i}$ is knowledge input proxied by the product and process innovation indicators. In our application we also include additional controls in equation (5). We take care of the endogeneity of $g_{i}$ in this equation by using in the estimation the predicted values from the knowledge production function equations (4).

In summary, our model consists of the four equations shown in equations (2), (3), (4) and (5). Since we assume a recursive model structure and do not allow for feedback effects, we follow a three-step estimation procedure. In the first step we estimate the generalized Tobit model (eqn. 2 and 3). In the second step, we separately estimate the two knowledge production functions for product and process innovations as two probit equations using the predicted value of innovative effort from the first step (to take care of both selectivity and endogeneity of $r_{i}^{*}$ in eqn 4). In the last step, we estimate the productivity equation using the predicted values from the second step (to take care of the endogeneity of $g_{i}$ in eqn 5). 


\section{Appendix B: Variable Definitions}

\section{Knowledge/Innovation:}

Continuous R\&D engagement: Dummy variable which takes the value 1 if the enterprise reports continuous engagement in intramural R\&D activities during the period 1998-2000.

R\&D intensity: R\&D expenditures per employee in 2000 (in logs).

Process innovation: Dummy variable which takes the value 1 if the enterprise reports having introduced new or significantly improved production processes during 1998-2000.

Product innovation: Dummy variable which takes the value 1 if the enterprise reports having introduced new or significantly improved products during 1998-2000 (new to the market or only new to the firm).

Share of sales with new products: Share of turnover in 2000 due to new or significantly improved products introduced during 1998-2000.

Labour productivity: Sales per employee in 2000 (in logs).

Investment intensity: Gross investments in tangible goods in 2000, per employee (in logs).

Public Support:

Local funding: Dummy variable which takes the value 1 if the enterprise received local or regional funding for innovation projects during 1998-2000.

National funding: Dummy variable which takes the value 1 if the enterprise received central government funding for innovation projects during 1998-2000.

EU funding: Dummy variable which takes the value 1 if the enterprise received EU funding for innovation projects during 1998-2000. 


\section{Demand Pull:}

Regulation and standards: Two variables which measure the share of firms for which regulation or standards were of high/medium and low importance for innovation during 1998-2000 at the 2-digit industry level, respectively [reference: no importance].

Environmental, health and safety aspects: Two variables which measure the share of firms for which improved environmental or health and safety aspects were of high/medium and low importance for innovation during 1998-2000 at the 2-digit industry level, respectively [reference: no importance].

\section{Sources of information:}

Internal sources within the enterprise: Dummy variable which takes the value 1 if information from internal sources within the enterprise were of high importance during 1998-2000.

Internal sources within the group: Dummy variable which takes the value 1 if information from internal sources within the enterprise group were of high importance during 1998-2000.

Universities as source of information: Dummy variable which takes the value 1 if information from universities or other higher education institutes were of high importance during 1998-2000.

Government as source of information: Dummy variable which takes the value 1 if information from government or private non-profit research institutes were of high importance during 19982000.

Suppliers as source of information: Dummy variable which takes the value 1 if information from suppliers were of high importance during 1998-2000.

Competitors as source of information: Dummy variable which takes the value 1 if information from competitors and other enterprises from the same industry were of high importance during 1998-2000.

Customers as source of information: Dummy variable which takes the value 1 if information from costumers or clients were of high importance during 1998-2000. 
Appropriability conditions:

Formal protection: Dummy variable which takes the value 1 if the enterprise used design pattern, trademarks or copyright to protect inventions or innovations during 1998-2000.

Strategic protection: Dummy variable which takes the value 1 if the enterprise used complexity of design, secrecy or lead-time advantage on competitors to protect inventions or innovations during 1998-2000.

Cooperation: Dummy variable which takes the value 1 if the enterprise had some co-operative arrangements on innovation activities during 1998-2000.

\section{Other:}

International competition: Dummy variable which takes the value 1 if the enterprise's most significant market is international.

Size: Set of size dummy variables according to the firm's number of employees in 1998. Categories are 20-49, 50-99, 100-249, 250-999, >1000 employees.

Industry: Set of industry dummies according to the firm's main business activity during the period 1998-2000. Classification: see Table B.1.

East Germany (for Germany only): Dummy variable which takes the value 1 if the enterprise is located in Eastern Germany. 
Table B.1: Number of firms by industry and corresponding proportions in total manufacturing for the four country samples

\begin{tabular}{|c|c|c|c|c|c|c|c|c|c|}
\hline \multirow[b]{2}{*}{ Industry } & \multirow[b]{2}{*}{ Nace } & \multicolumn{2}{|c|}{ France } & \multicolumn{2}{|c|}{ Germany } & \multicolumn{2}{|c|}{ Spain } & \multicolumn{2}{|c|}{ UK } \\
\hline & & & $\%$ & & $\%$ & & $\%$ & & $\%$ \\
\hline Textile & $17-19$ & 496 & 13.7 & 72 & 6.4 & 598 & 16.7 & 115 & 6.0 \\
\hline Wood/paper & $20-22$ & 429 & 11.8 & 97 & 8.6 & 500 & 13.9 & 288 & 15.1 \\
\hline Chemicals & $23-24$ & 343 & 9.5 & 89 & 7.9 & 316 & 8.8 & 90 & 4.7 \\
\hline Plastic/rubber & 25 & 278 & 7.7 & 103 & 9.2 & 167 & 4.7 & 106 & 5.6 \\
\hline Non-metallic & 26 & 166 & 4.6 & 64 & 5.7 & 289 & 8.0 & 46 & 2.4 \\
\hline Basis metals & $27-28$ & 625 & 17.3 & 209 & 18.6 & 536 & 14.9 & 251 & 13.2 \\
\hline Machinery & 29 & 429 & 11.8 & 187 & 16.7 & 242 & 6.7 & 164 & 8.6 \\
\hline Electrical & $30-33$ & 472 & 13.0 & 199 & 17.7 & 332 & 9.3 & 342 & 18.0 \\
\hline Vehicles & $34-35$ & 200 & 5.5 & 58 & 5.2 & 257 & 7.2 & 232 & 12.2 \\
\hline Nec & 36 & 187 & 5.2 & 45 & 4.0 & 351 & 9.8 & 270 & 14.2 \\
\hline All firms & & 3625 & 100 & 1123 & 100 & 3588 & 100 & 1904 & 100 \\
\hline
\end{tabular}

Notes: Data are from the CIS 3 in each country. The industry definition is based on the classification system NACE Rev.1 (Nomenclature générale des activités économiques dans les Communautés Européennes) as published by Eurostat (1992), using 2-digit levels. 
Table 1: Aggregate productivity and R\&D intensity across countries

\begin{tabular}{|c|c|c|c|c|c|}
\hline & USA & FRA & GER & SPA & UK \\
\hline GDP per capita in 2000 (in US \$) & 34602 & 25293 & 24851 & 20317 & 25322 \\
\hline$R \& D$ intensity in 2000 & 2.72 & 2.18 & 2.49 & 0.94 & 1.86 \\
\hline $\begin{array}{l}\text { Average annual growth rate in labour } \\
\text { productivity } 1995-2000\end{array}$ & 1.6 & 1.3 & 1.1 & 0.7 & 1.6 \\
\hline $\begin{array}{l}\text { Average annual growth rate in multi-factor } \\
\text { productivity } 1995-2000\end{array}$ & 1.3 & 0.8 & 1.0 & n.a. & 0.9 \\
\hline
\end{tabular}

Notes: The averages are calculated as the geometric mean. The R\&D intensity is the gross domestic expenditures on R\&D as a percentage of GDP. The growth of labour productivity is obtained by dividing the growth of value added at constant prices by the growth of the labour force. The rate of multi-factor productivity growth is the part of GDP growth which is not explained by the weighted average of the rates of growth of capital and labour inputs. The data are from OECD (2005a, b). 
Table 2: Means of variables across countries

\begin{tabular}{|c|c|c|c|c|}
\hline & France & Germany & Spain & UK \\
\hline \multicolumn{5}{|l|}{ Knowledge/Innovation: } \\
\hline Continuous R\&D engagement & 0.350 & 0.395 & 0.209 & 0.267 \\
\hline R\&D per employee (for firms with continuous R\&D engagement) & 6.929 & 5.238 & 4.327 & 3.563 \\
\hline Innovator (product and/or process innovation) & 0.529 & 0.658 & 0.512 & 0.415 \\
\hline Process innovation & 0.323 & 0.423 & 0.347 & 0.271 \\
\hline Product innovation & 0.446 & 0.547 & 0.336 & 0.286 \\
\hline Share of sales with new products (for firms with product innovation) & 0.165 & 0.295 & 0.327 & 0.308 \\
\hline Labour productivity & 165.275 & 145.646 & 137.724 & 143.435 \\
\hline Investment per employee & 6.025 & 8.321 & $8.338^{\mathrm{a}}$ & 6.263 \\
\hline \multicolumn{5}{|l|}{ Public Support: } \\
\hline Local funding & 0.055 & 0.158 & 0.140 & 0.045 \\
\hline National funding & 0.154 & 0.212 & 0.125 & 0.036 \\
\hline EU funding & 0.051 & 0.081 & 0.033 & 0.017 \\
\hline \multicolumn{5}{|l|}{ Demand Pull: } \\
\hline Environmental, health and safety aspects: low importance & 0.134 & 0.186 & 0.066 & 0.214 \\
\hline Environmental, health and safety aspects: medium or high importance & 0.273 & 0.256 & 0.263 & 0.228 \\
\hline Regulations and standards: low importance & 0.115 & 0.160 & 0.059 & 0.169 \\
\hline Regulations and standards: medium or high importance & 0.307 & 0.264 & 0.282 & 0.278 \\
\hline \multicolumn{5}{|l|}{ Sources of information: } \\
\hline Internal sources within the enterprise & 0.317 & 0.303 & 0.227 & 0.263 \\
\hline Internal sources within the group & 0.095 & 0.117 & 0.086 & 0.088 \\
\hline Universities as source of information & 0.016 & 0.079 & 0.025 & 0.017 \\
\hline Government as source of information & 0.017 & 0.029 & 0.035 & 0.005 \\
\hline Suppliers as source of information & 0.092 & 0.129 & 0.126 & 0.135 \\
\hline Competitors as source of information & 0.125 & 0.113 & 0.057 & 0.063 \\
\hline Customers as source of information & 0.253 & 0.322 & 0.126 & 0.145 \\
\hline Observations & 3625 & 1123 & 3588 & 1904 \\
\hline
\end{tabular}


Table 2 (continued): Means of variables across countries

\section{France Germany}

Spain

UK

\section{Appropriability conditions:}

Formal protection

$\begin{array}{llll}0.330 & 0.358 & 0.106 & 0.374 \\ 0.267 & 0.519 & 0.129 & 0.514 \\ 0.261 & 0.246 & 0.114 & 0.157\end{array}$

Cooperation

0.261

0.246

0.157

Other:

International competition

$\begin{array}{llll}0.407 & 0.407 & 0.175 & 0.209\end{array}$

Size: $<50$

$\begin{array}{llll}0.304 & 0.288 & 0.478 & 0.386\end{array}$

Size: 50-99

0.192

0.205

$0.219 \quad 0.222$

Size: $100-250$

$0.204 \quad 0.223$

$0.156 \quad 0.171$

Size: 250-999

0.227

0.224

0.127

0.188

Size $>1000$

0.073

0.061

0.020

0.033

East German (only in Germany)

0.303

Observations

3625

1123

3588

1904

Notes: Data are from the Community Innovation Survey, Wave 3 in each country. All variables cover the years 19982000, with the exception of R\&D per employee, labour productivity and investment per employee (related to the year 2000) and size (related to the number of employees in the year 1998). All values are in thousands of Euros, exchange rate for the UK is 1.6422 Euros per pound sterling. 
Table 3 (left panel): R\&D equations: selection equation

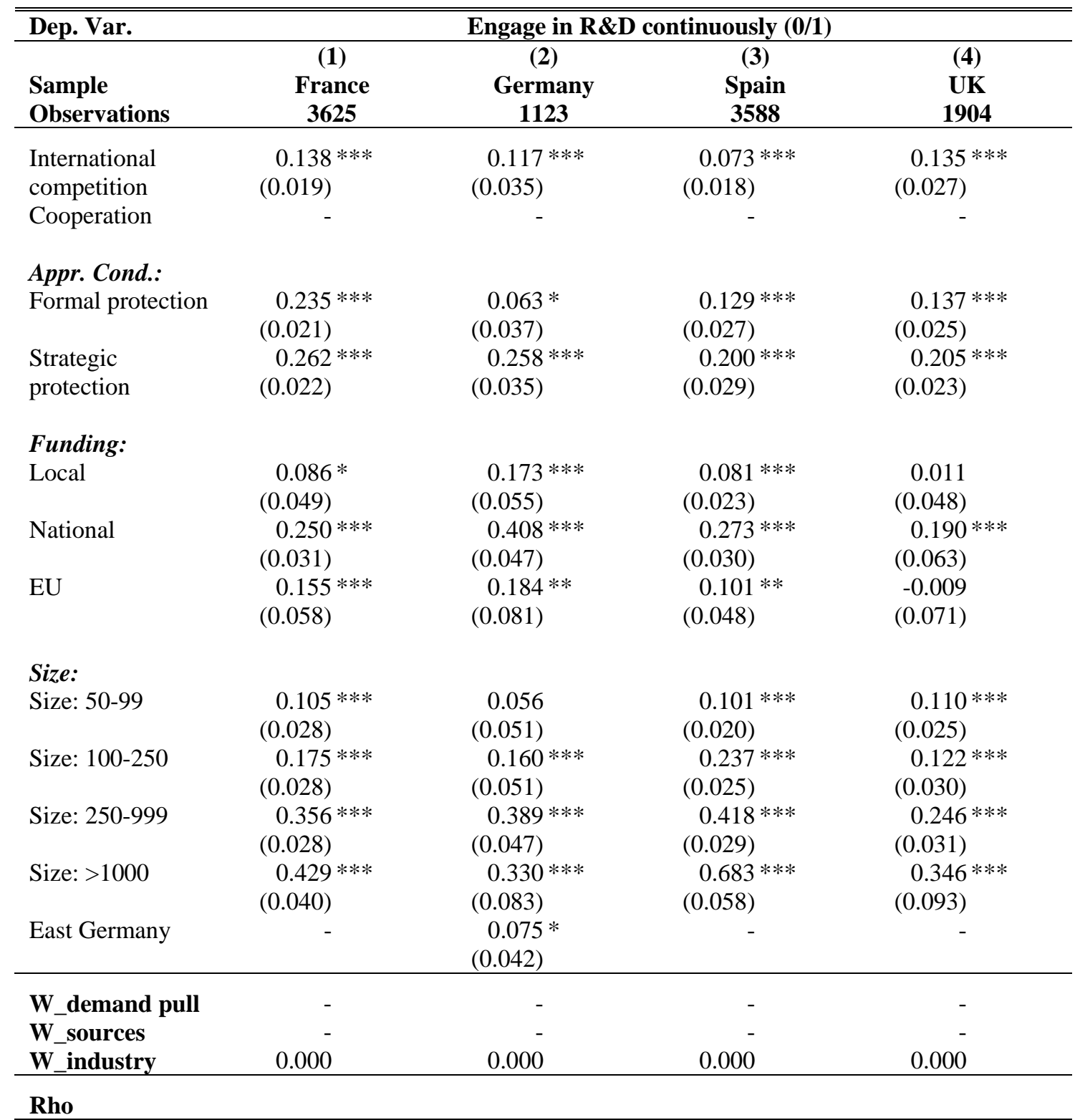

\footnotetext{
Log-Likelihood

Notes: Standard errors in parentheses are robust. Reported are marginal effects (at the sample means) for the probability of doing R\&D continuously and for the expected value of the R\&D intensity conditional on doing R\&D, respectively. Industry dummies are included in both equations; demand pull variables and sources of information are included in the R\&D intensity. Corresponding marginal effects are not shown, but W reports the p-value of a test of the joint significance of the defined variables.
} 
Table 3 (right panel): R\&D equations: intensity equation

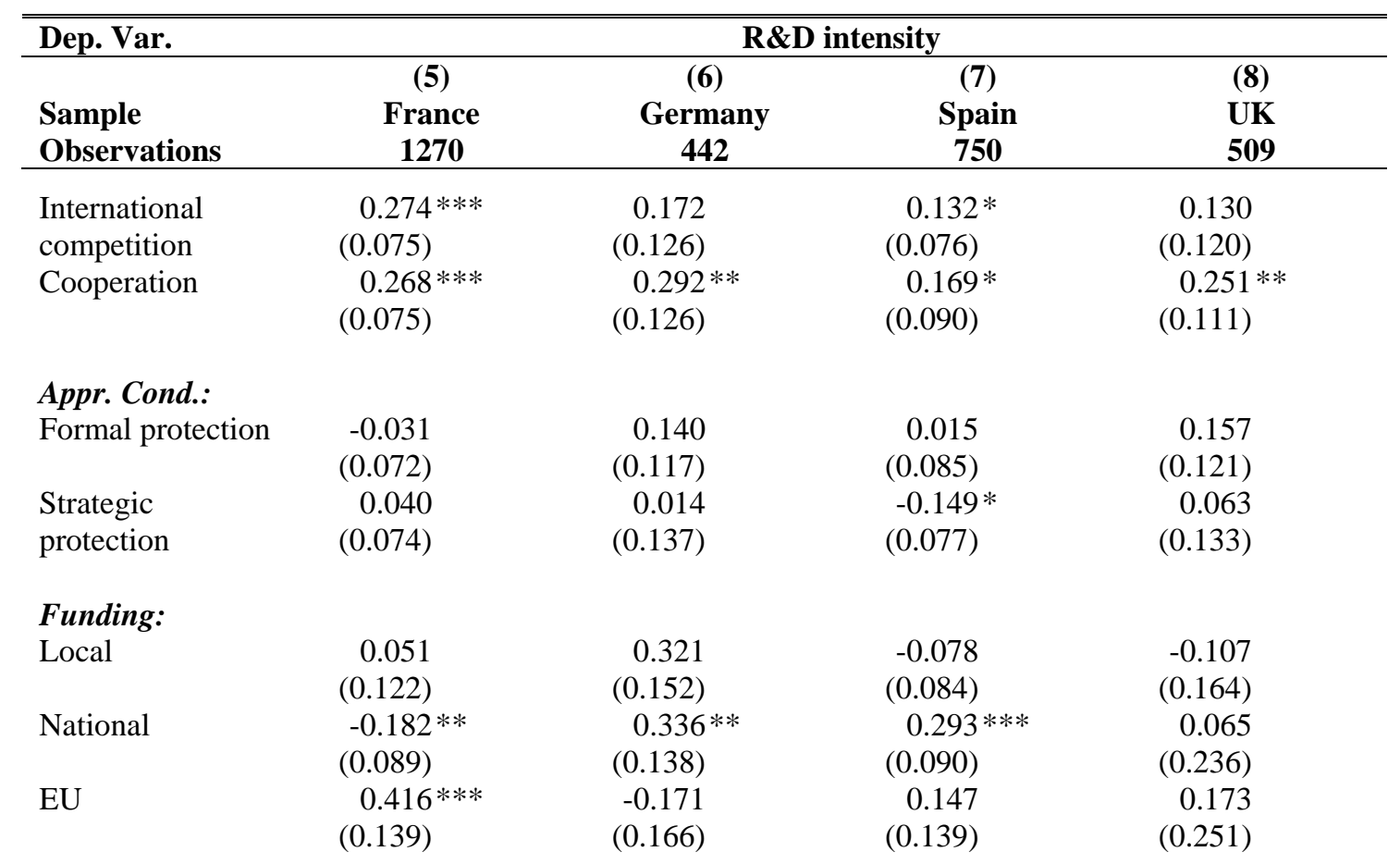

Size:

Size: 50-99

Size: $100-250$

Size: 250-999

Size: $>1000$

East Germany

0.121

(0.139)

\begin{tabular}{lrrrr}
\hline W_demand pull & 0.000 & 0.309 & 0.312 & 0.880 \\
W_sources & 0.062 & 0.285 & 0.159 & 0.313 \\
W_industry & 0.000 & 0.000 & 0.000 & 0.000 \\
\hline Rho & 0.366 & 0.443 & 0.745 & 0.819 \\
& $(0.050)$ & $(0.066)$ & $(0.056)$ & $(0.045)$ \\
\hline
\end{tabular}

$\begin{array}{lllll}\text { Log-Likelihood } & -3594.3 & -1199.7 & -2135.7 & -1593.0\end{array}$

Notes: Standard errors in parentheses are robust. Reported are marginal effects (at the sample means) for the probability of doing R\&D continuously and for the expected value of the R\&D intensity conditional on doing $R \& D$, respectively. Industry dummies are included in both equations; demand pull variables and sources of information are included in the R\&D intensity. Corresponding marginal effects are not shown, but $\mathrm{W}$ reports the p-value of a test of the joint significance of the defined variables. 
Table 4 (left panel): Knowledge production function: Process Innovation

\begin{tabular}{|c|c|c|c|c|}
\hline \multirow[t]{2}{*}{ Dep. Var. } & \multicolumn{4}{|c|}{ Process Innovation (0/1) } \\
\hline & (1) & (2) & (3) & (4) \\
\hline Sample & France & Germany & Spain & UK \\
\hline Observations & 3625 & 1123 & 3588 & 1904 \\
\hline \multirow[t]{2}{*}{ R\&D intensity } & $0.303 * * *$ & $0.260 * * *$ & $0.281 * * *$ & $0.161^{* * *}$ \\
\hline & $(0.029)$ & $(0.036)$ & $(0.025)$ & $(0.034)$ \\
\hline \multirow[t]{2}{*}{ Investment intensity } & $0.023 * * *$ & $0.022 *$ & $0.029 * * *$ & $0.037 * * *$ \\
\hline & $(0.006)$ & $(0.012)$ & $(0.004)$ & $(0.007)$ \\
\hline \multicolumn{5}{|l|}{ Appr. Cond.: } \\
\hline \multirow[t]{2}{*}{ Formal protection } & $0.035 *$ & 0.025 & -0.031 & $-0.097 * * *$ \\
\hline & $(0.021)$ & $(0.038)$ & $(0.031)$ & $(0.032)$ \\
\hline \multirow[t]{2}{*}{ Strategic protection } & $0.075 * * *$ & 0.030 & $0.068 * *$ & 0.012 \\
\hline & $(0.025)$ & $(0.041)$ & $(0.034)$ & $(0.042)$ \\
\hline \multicolumn{5}{|l|}{ Sources: } \\
\hline \multirow[t]{2}{*}{ Suppliers } & $0.243 * * *$ & $0.331 * * *$ & $0.405 * * *$ & $0.407^{* * *}$ \\
\hline & $(0.034)$ & $(0.047)$ & $(0.028)$ & $(0.042)$ \\
\hline \multirow[t]{2}{*}{ Competitors } & $0.062 * *$ & 0.042 & $0.187 * * *$ & 0.026 \\
\hline & $(0.028)$ & $(0.053)$ & $(0.046)$ & $(0.049)$ \\
\hline Customers & - & - & - & - \\
\hline \multicolumn{5}{|l|}{ Demand Pull: } \\
\hline \multirow[t]{2}{*}{ Environ. Aspects low } & $0.717 * *$ & $0.520 * *$ & $0.916 * * *$ & 0.125 \\
\hline & $(0.332)$ & $(0.245)$ & $(0.254)$ & $(0.250)$ \\
\hline \multirow[t]{2}{*}{ Environ. Aspects high } & $1.425 * * *$ & $0.736 * * *$ & -0.003 & 0.196 \\
\hline & $(0.243)$ & $(0.237)$ & $(0.234)$ & $(0.197)$ \\
\hline \multirow[t]{2}{*}{ Standards low } & $-0.583 *$ & $-0.795 * * *$ & $-0.474 *$ & -0.046 \\
\hline & $(0.324)$ & $(0.279)$ & $(0.263)$ & $(0.248)$ \\
\hline \multirow[t]{2}{*}{ Standards high } & $-1.288 * * *$ & -0.251 & -0.258 & -0.014 \\
\hline & $(0.241)$ & $(0.227)$ & $(0.231)$ & $(0.224)$ \\
\hline \multicolumn{5}{|l|}{ Size: } \\
\hline \multirow[t]{2}{*}{ Size: 50-99 } & 0.028 & 0.062 & 0.015 & 0.011 \\
\hline & $(0.025)$ & $(0.049)$ & $(0.023)$ & $(0.029)$ \\
\hline \multirow[t]{2}{*}{ Size: $100-250$} & $0.063 * *$ & $0.183 * * *$ & -0.001 & $0.070 * *$ \\
\hline & $(0.025)$ & $(0.047)$ & $(0.026)$ & $(0.034)$ \\
\hline \multirow[t]{2}{*}{ Size: 250-999 } & $0.084 * * *$ & $0.225 * * *$ & $0.101^{* * *}$ & $0.146 * * *$ \\
\hline & $(0.026)$ & $(0.048)$ & $(0.031)$ & $(0.035)$ \\
\hline \multirow[t]{2}{*}{ Size: $>1000$} & $0.131 * * *$ & $0.238 * * *$ & $0.255 * * *$ & 0.060 \\
\hline & $(0.042)$ & $(0.077)$ & $(0.081)$ & $(0.071)$ \\
\hline East Germany & - & $\begin{array}{r}-0.018 \\
(0.040)\end{array}$ & - & - \\
\hline W_industry & 0.000 & 0.000 & 0.000 & 0.038 \\
\hline Pseudo R2 & 0.213 & 0.202 & 0.225 & 0.184 \\
\hline Log-Likelihood & -1794.9 & -610.5 & -1796.0 & -908.1 \\
\hline
\end{tabular}

Notes: Standard errors in parentheses are robust. Numbers reported are the marginal effects (at the sample means) from a probit. W_industry reports the p-value of a test of the joint significance of the industry dummies. 
Table 4 (right panel): Knowledge production function: Product Innovation

\begin{tabular}{|c|c|c|c|c|}
\hline \multirow[t]{2}{*}{ Dep. Var. } & \multicolumn{4}{|c|}{ Product Innovation (0/1) } \\
\hline & $\begin{array}{c}\text { (5) } \\
\text { France }\end{array}$ & $\begin{array}{c}\text { (6) } \\
\text { Germany }\end{array}$ & $\begin{array}{c}\text { (7) } \\
\text { Spain }\end{array}$ & $\begin{array}{l}\text { (8) } \\
\text { UK }\end{array}$ \\
\hline Observations & 3625 & 1123 & 3588 & 1904 \\
\hline R\&D intensity & $\begin{array}{l}0.440 * * * \\
(0.038)\end{array}$ & $\begin{array}{l}0.273 * * * \\
(0.043)\end{array}$ & $\begin{array}{l}0.296 * * * \\
(0.026)\end{array}$ & $\begin{array}{l}0.273^{* * *} \\
(0.036)\end{array}$ \\
\hline Investment intensity & - & - & - & - \\
\hline \multicolumn{5}{|l|}{ Appr. Cond.: } \\
\hline Formal protection & $\begin{array}{l}0.134^{* * *} \\
(0.025)\end{array}$ & $\begin{array}{c}0.087 * * \\
(0.040)\end{array}$ & $\begin{array}{l}0.077^{* *} \\
(0.034)\end{array}$ & $\begin{array}{r}-0.046 \\
(0.034)\end{array}$ \\
\hline Strategic protection & $\begin{array}{l}0.100 * * * \\
(0.030)\end{array}$ & $\begin{array}{l}0.143 * * * \\
(0.043)\end{array}$ & $\begin{array}{c}0.059 * \\
(0.034)\end{array}$ & $\begin{array}{r}-0.007 \\
(0.042)\end{array}$ \\
\hline \multicolumn{5}{|l|}{ Sources: } \\
\hline Suppliers & - & - & - & - \\
\hline Competitors & $\begin{array}{l}0.125^{* * * *} \\
(0.038)\end{array}$ & $\begin{array}{r}0.028 \\
(0.066)\end{array}$ & $\begin{array}{c}0.089 * \\
(0.048)\end{array}$ & $\begin{array}{r}0.014 \\
(0.056)\end{array}$ \\
\hline Customers & $\begin{array}{l}0.335^{* * * *} \\
(0.024)\end{array}$ & $\begin{array}{l}0.290 * * * \\
(0.037)\end{array}$ & $\begin{array}{l}0.381 * * * \\
(0.030)\end{array}$ & $\begin{array}{l}0.312^{* * *} \\
(0.047)\end{array}$ \\
\hline \multicolumn{5}{|l|}{ Demand Pull: } \\
\hline Environ. Aspects low & $\begin{array}{l}1.290 * * * \\
(0.467)\end{array}$ & $\begin{array}{r}0.130 \\
(0.253)\end{array}$ & $\begin{array}{r}0.032 \\
(0.248)\end{array}$ & $\begin{array}{r}0.022 \\
(0.254)\end{array}$ \\
\hline Environ. Aspects high & $\begin{array}{l}1.526 * * * \\
(0.324)\end{array}$ & $\begin{array}{r}0.366 \\
(0.255)\end{array}$ & $\begin{array}{r}-0.198 \\
(0.226)\end{array}$ & $\begin{array}{r}0.395 \\
(0.203)\end{array}$ \\
\hline Standards low & $\begin{array}{r}-0.647 \\
(0.463)\end{array}$ & $\begin{array}{r}0.028 \\
(0.295)\end{array}$ & $\begin{array}{r}0306 \\
(0.254)\end{array}$ & $\begin{array}{r}-0.147 \\
(0.251)\end{array}$ \\
\hline Standards high & $\begin{array}{l}-1.434 * * * \\
(0.323)\end{array}$ & $\begin{array}{r}0.114 \\
(0.244)\end{array}$ & $\begin{array}{l}0.622 \text { *** } \\
(0.222)\end{array}$ & $\begin{array}{r}-0.312 \\
(0.229)\end{array}$ \\
\hline \multicolumn{5}{|l|}{ Size: } \\
\hline Size: 50-99 & $\begin{array}{l}0.093 \text { *** } \\
(0.028)\end{array}$ & $\begin{array}{r}0.076 \\
(0.049)\end{array}$ & $\begin{array}{l}-0.044^{*} \\
(0.022)\end{array}$ & $\begin{array}{r}0.021 \\
(0.030)\end{array}$ \\
\hline Size: $100-250$ & $\begin{array}{r}0.009 \\
(0.028)\end{array}$ & $\begin{array}{r}0.037 \\
(0.048)\end{array}$ & $\begin{array}{l}0.070 * * * \\
(0.026)\end{array}$ & $\begin{array}{r}-0.004 \\
(0.033)\end{array}$ \\
\hline Size: 250-999 & $\begin{array}{l}0.087^{* * * *} \\
(0.030)\end{array}$ & $\begin{array}{l}0.147 * * * \\
(0.049)\end{array}$ & $\begin{array}{l}0.097 * * * \\
(0.031)\end{array}$ & $\begin{array}{r}0.013 \\
(0.031)\end{array}$ \\
\hline Size: $>1000$ & $\begin{array}{r}0.050 \\
(0.050)\end{array}$ & $\begin{array}{r}0.097 \\
(0.090)\end{array}$ & $\begin{array}{l}0.259 * * * \\
(0.083)\end{array}$ & $\begin{array}{r}0.049 \\
(0.061)\end{array}$ \\
\hline East Germany & - & $\begin{array}{r}0.014 \\
(0.044)\end{array}$ & - & - \\
\hline W_industry & 0.000 & 0.000 & 0.000 & 0.005 \\
\hline Pseudo R2 & 0.360 & 0.313 & 0.249 & 0.258 \\
\hline Log-Likelihood & -1595.3 & -531.2 & -1719.1 & -846.1 \\
\hline
\end{tabular}

Notes: Standard errors in parentheses are robust. Numbers reported are the marginal effects (at the sample means) from a probit. W_industry reports the p-value of a test of the joint significance of the industry dummies. 
Table 5: Output Production Function

\begin{tabular}{|c|c|c|c|c|}
\hline \multirow[t]{2}{*}{ Dep. Var. } & \multicolumn{4}{|c|}{ Labour productivity } \\
\hline & (1) & (2) & (3) & (4) \\
\hline Sample & France & Germany & Spain & UK \\
\hline Observations & 3625 & 1123 & 3588 & 1904 \\
\hline Investment intensity & $\begin{array}{l}0.130^{* * *} \\
(0.010)\end{array}$ & $\begin{array}{l}0.109 * * * \\
(0.014)\end{array}$ & $\begin{array}{l}0.061 * * * \\
(0.006)\end{array}$ & $\begin{array}{l}0.059^{* * * *} \\
(0.010)\end{array}$ \\
\hline Process innovation & $\begin{array}{l}0.069 * * \\
(0.033)\end{array}$ & $\begin{array}{r}0.022 \\
(0.050)\end{array}$ & $\begin{array}{r}-0.038 \\
(0.043)\end{array}$ & $\begin{array}{r}0.029 \\
(0.035)\end{array}$ \\
\hline Product innovation & $\begin{array}{l}0.060 * * * \\
(0.020)\end{array}$ & $\begin{array}{r}-0.053 \\
(0.034)\end{array}$ & $\begin{array}{l}0.176 * * * \\
(0.034)\end{array}$ & $\begin{array}{l}0.055^{* *} \\
(0.024)\end{array}$ \\
\hline Size: 50-99 & $\begin{array}{l}-0.091 * * * \\
(0.029)\end{array}$ & $\begin{array}{c}0.083 * \\
(0.049)\end{array}$ & $\begin{array}{c}0.108 * * \\
(0.045)\end{array}$ & $\begin{array}{l}0.070^{* *} \\
(0.035)\end{array}$ \\
\hline Size: 100-249 & $\begin{array}{l}-0.059 * * \\
(0.030)\end{array}$ & $\begin{array}{l}0.250 * * * \\
(0.053)\end{array}$ & $\begin{array}{l}0.152 \text { *** } \\
(0.056)\end{array}$ & $\begin{array}{l}0.153^{* * * *} \\
(0.041)\end{array}$ \\
\hline Size: 250-999 & $\begin{array}{r}0.024 \\
(0.031)\end{array}$ & $\begin{array}{l}0.281 * * * \\
(0.055)\end{array}$ & $\begin{array}{l}0.350 * * * \\
(0.061)\end{array}$ & $\begin{array}{l}0.274^{* * *} \\
(0.046)\end{array}$ \\
\hline Size: $>1000$ & $\begin{array}{l}0.183^{* * *} \\
(0.044)\end{array}$ & $\begin{array}{l}0.455 * * * \\
(0.083)\end{array}$ & $\begin{array}{l}0.510 * * * \\
(0.109)\end{array}$ & $\begin{array}{l}0.268^{* *} \\
(0.118)\end{array}$ \\
\hline East Germany & - & $\begin{array}{l}-0.293 * * * \\
(0.035)\end{array}$ & - & - \\
\hline Constant & $\begin{array}{l}4.770 * * * \\
(0.052)\end{array}$ & $\begin{array}{l}4.370 * * * \\
(0.093)\end{array}$ & $\begin{array}{l}3.692 * * * \\
(0.078)\end{array}$ & $\begin{array}{l}4.262 \text { *** } \\
(0.063)\end{array}$ \\
\hline R2 & 0.29 & 0.28 & 0.18 & 0.19 \\
\hline Observations & 3625 & 1123 & 3588 & 1904 \\
\hline
\end{tabular}

Notes: Standard errors in parentheses are robust. Numbers reported are coefficients from an IV regression.

Industry dummies are included in all regressions. 


\section{References}

Abramovsky, L., Jaumandreu, J., Kremp, E. and Peters, B. (2004), National Differences in Innovation Behaviour: Facts and mimeo, http://www.eco.uc3m.es/IEEF/documentpapers.html.

Aghion, P. and Howitt, P. (1998), Endogenous Growth Theory, MIT Press.

Aschhoff, B., Doherr, T., Ebersberger, B., Peters, B. Rammer, C. and Schmidt, T. (2006), Innovation in Germany: Results from the Innovation Survey 2005, Mannheim.

Benavente J.M. (2006), 'The role of research and innovation in promoting productivity in Chile', Economics of Innovation and New Technology, 15(4/5), 301-315. Special Issue 'On Empirical Studies of Innovation in the Knowledge Driven Economy’.

Cohen, W. and Klepper, S. (1996), A Reprise of Size and R\&D, The Economic Journal, 106 (437), 925-951.

Crepon, B., Duguet, E. and Mairesse, J. (1998), 'Research and Development, Innovation and Productivity: An Econometric Analysis at the Firm Level', Economics of Innovation and New Technology, 7(2), 115-58.

Criscuolo, C. and Haskell, J. (2003), 'Innovations and Productivity Growth in the UK: Evidence from CIS2 and CIS3’, CeRiBA Discussion Paper, EBPF03-3(10), London.

Czarnitzki, D. and Licht, G. (2006), 'Additionality of Public R\&D Grants in a Transition Economy: The Case of Eastern Germany’, Economics of Transition, 14(1), 101-31.

EU (2003), An agenda for a growing Europe: making the EU economic system deliver, Report of an Independent High-Level Study group established on the initiative of the President of the European Commission, July 2003.

EUROSTAT (1992) Nace Rev. 1, Paris. 
EUROSTAT (2004), Innovation in Europe. Results for the EU, Iceland and Norway, Luxemburg.

Griliches, Z. (1979), 'Issues in assessing the contribution of research and development to productivity growth', Bell Journal of Economics, 10(1), 92-116.

Griliches, Z. (1994), 'Productivity, R\&D, and the Data Constraint', American Economic Review, 84(1), 1-23.

Griliches, Z. (1996), 'R\&D and Productivity: The Unfinished Business', in Griliches, Z. (ed.) (1998), R\&D and Productivity: The Econometric Evidence, Chicago and London, University of Chicago Press.

Griliches, Z. and Mairesse, J. (1998), 'Production Functions: The search for Identification', in Strom, S. (ed.), Econometrics and Economic Theory in the Twentieth Century: The Ragnar Frisch Centennial Symposium, 169-203, Cambridge, Cambridge University Press.

Hall B.H. and J. Mairesse (2006), 'Empirical Studies of Innovation in the Knowledge Driven Economy: Introduction', Economics of Innovation and New Technology, 15(4/5), 289-299.

Huergo, E. and Moreno, L. (2006): “La productividad de las empresas manufactureras españolas en los noventa”, in Segura, J. (coord.): El crecimiento de la productividad en España, Fundación Ramón Areces, Madrid.

Janz, N., Lööf, H. and Peters, B. (2004), 'Firm Level Innovation and Productivity - Is There a Common Story Across Countries?', Problems and Perspectives in Management, 2, 184-204.

Jefferson, G., Huamao, B., Xiaojing, G. and Xiaoyun Y. (2006), 'R\&D Performance in Chinese Industry', Economics of Innovation and New Technology, 15(4/5), 345-366. Special Issue 'On Empirical Studies of Innovation in the Knowledge Driven Economy’.

Klomp, L. and Van Leeuwen, G. (2001), 'Linking Innovation and Firm Performance: A New Approach', International Journal of the Economics of Business, 8(3), 343-364. 
Lööf, H. and Heshmati, A. (2002), 'Knowledge Capital and Performance Heterogeneity: A Firm Level Innovation Study’, International Journal of Production Economics, 76(1), 61-85.

Lööf, H .and Heshmati, A. (2006), 'Knowledge capital and heterogeneity in firm performance. A sensitivity analysis', Economics of Innovation and New Technology, 15(4/5), 317-344. Special Issue ‘On Empirical Studies of Innovation in the Knowledge Driven Economy’.

Mairesse, J. and Mohnen, P. (2005), ‘Accounting for Innovation and Measuring Innovativeness: An Illustrative Framework and an Application', American Economic Review, 92 (2), 226-230.

Mairesse, J. and Mohnen, P. (2005), 'The Importance of R\&D for Innovation: A Reassessment Using French Survey Data', The Journal of Technology Transfer, 30(1-2), 183-197.

Mairesse, J. and Jaumandreu, J. (2005), “Panel-data Estimates of the Production Function and the Revenue Function: What Difference Does It Make?”, Scandinavian Journal of Economics, 107(4), 2005, 651-672.

Mohnen, P., Mairesse, J. and Dagenais, M. (2006), 'Innovativity: A Comparison across Seven European Countries', Economics of Innovation and New Technology, 15(4/5), 391-413. Special Issue ”On Empirical Studies of Innovation in the Knowledge Driven Economy”.

OECD (1963), 'The Measurement of Scientific and Technical Activities- Frascati Manual', OECD, Paris.

OECD (2005a), OECD Factbook 2005, Paris

OECD (2005b), OECD Science, Technology and Industry Scoreboard, Paris.

OECD and Eurostat (2005), 'Proposed Guidelines for Collecting and Interpreting Technological Innovation Data- Oslo Manual’, third edition, OECD, Paris.

Parisi, M., Schiantarelli, F. and Sembenelli, A. (2005), 'Productivity, Innovation and R\&D: Micro Evidence for Italy', European Economic Review, forthcoming.

Peters, B. (2006), Innovation and Firm Performance: An Empirical Investigation for German Firms, PhD thesis, University of Wuerzburg. 
Spence, M. (1984), Cost Reduction, Competition and Industry Performance, Econometrica 52, $101-121$

Van Leeuwen, G. and Klomp, L. (2006), 'On the Contribution of Innovation to Multi-Factor Productivity Growth', Economics of Innovation and New Technology, 15(4/5), 367-390. Special Issue ”On Empirical Studies of Innovation in the Knowledge Driven Economy”. 